\title{
Linguistic Representation of Family Relations in Russian and Yemeni Set Expressions
}

\author{
Abdulrakib A. Alavi ${ }^{1} \&$ Timur A. Shaikhullin ${ }^{2}$ \\ ${ }^{1}$ Kazan (Volga Region) Federal University, Kazan, Russia \\ ${ }^{2}$ Russian Islamic Institute, Kazan, Russia \\ Correspondence: Abdulrakib Abdulmaged Alavi, Kazan (Volga Region) Federal University, Kremlyovskaya \\ Street 18, Kazan 420008, Russia. E-mail: rakibalawi@yahoo.com
}

Received: April 14, 2015 Accepted: April 20, 2015 Online Published: April 27, 2015

doi:10.5539/jsd.v8n4p268 URL: http://dx.doi.org/10.5539/jsd.v8n4p268

\begin{abstract}
The significance of the present study is caused by an intensive development of comparative linguistics in respect of the specification and improvement of its fundamental theoretical principles, as well as concerning particular descriptions of the separate language facts. The article presents a complex comparative research of Russian and Yemeni paroemias reflecting specific character of family relations in conceptual-semantic and ethno cultural aspects. The objective of the article is to consider peculiarities of the worldview of Russian and Yemeni people, which are presented in the set expressions reflecting national and cultural specifics of Russian and Arab linguistic cultures. The article highlights identical features and distinctions between paroemias of the both languages with "family" lexeme and "family relations" semantic field. Theoretical information and language base covered in the article can be used in teaching vocabulary of modern Russian and Arabic languages, Arabic dialectology, Linguistic culture, Cross-cultural communication; as well as in teaching special courses on language and culture issues to students specializing in "linguistics" and "philology". Applied value of the present study is determined by the possibility of practical usage of the information given in compiling textbooks, study guides and dictionaries of Arabic and Russian languages.
\end{abstract}

Keywords: Russian paroemias, Yemeni paroemias, a family, family relations

\section{Introduction}

Proclaiming humanism and sensible norms of human society, proverbial folklore of the Russian and Arabic languages isn't deprived of the contradictions risen by the contradictions of life itself. It is known that along with the literary Arabic language - official language of Arab countries, there are local (territorial) dialects with peculiar accents and parlance. According to A.G. Belova, Arab dialects appeared and started developing from ancient times "along with the poetic and sacral language as a common "everyday" language of tradespeople, camelcade guides carrying out economic relations between the Bedouins and settled population, as well as between different trade and religious centers of Arabia" (Belova, 1999). G. Sh. Sharbatov classifies dialects of the Arabic language as follows: Iraqi, Arabian, Yemeni, Syrian, Lebanese, Egyptian, Sudanese and the so-called Maghrebian - Lybian, Tunisian, Algerian, Moroccan (Sharbatov, 1961). The present study considers specific features of the set expressions of the Yemeni dialect of the Arabic language in comparison with Russian paroemias.

Paroemias (proverbs, sayings and aphorisms) - small genres of folklore - hold a special place among various works of folklore. Comparative study of paroemias in structurally different languages is significant due to their laconism and fixed form, astonishing content capacity, rhythmic system and age of forming. Paroemias about a family reflect the person's "inner" world, relationships in the family and starting one's own home life. The importance of a family in the life of a person is reflected in numerous Russian and Yemeni paroemias about a family. The article examines 97 Yemeni and 120 Russian paroemias reflecting the specific features of family relations. The figures show that the amount of Russian proverbs of the give semantic field prevails over the amount of Yemeni proverbs. According to E.I. Ivanova, this difference causes more detailed specification of the proverbial cognitive space regarding total amount of concepts as well as more detailed specification of identical concepts (Ivanova, 2002). 
Despite the great amount of similar features of the concepts described by the proverbs of the languages which are compared, concepts which are unique for each nation were also revealed during the analysis of paroemiological corpus. Rich folklore language is reflected in the paroemias of both languages considered in the article; specific character of relations with family members, social and moral ethical standards are revealed.

Aiming to provide more detailed analysis of the above mentioned semantic group, we consider it viable to give the definition of the term "family" from Russian and Arabic defining dictionaries.

Family - a group of close relatives living together; parents with children; a married son or daughter living separately make another family (Dal', 1955).

Family - 1. A group of close relatives living together. 2. A group of people united by common interests. 3. A group of animals, birds, consisting of a male, female and younglings and an isolated group of some animals, plants or mushrooms of the same kind (Ojegov, 2007).

عائلة $\bar{A}$ ALA family - those people who have a common house with parents, children and relatives. This lexeme is derived from the verb عال'ÁAA to feed, to keep (a family). The active voice participle is translated as $a$ breadwinner (for the family) (al-mujam al-wasit, 2012).

عائلة 'ÁILA family - when they speak about a man's family, they mean his wife and children who sponge on him for a living ; and relatives by his father's side. (al-munjid al-adjadiyy, 2014).

Russian and Arabic linguistic cultures have both the peculiarities and similarities, due to the fact that the concept family is the fundamental concept for any culture, any people. Their comparative study can reveal not only specific features of the formation of a Russian or Yemeni family, but also extra linguistic conditions of its formation. N.M. Zhanpeisova notes that "meanings, characterizing different tendencies of social relationships, ethical standards peculiar to the cultures which are compared are reflected in the corpus of the proverbs considered" (Zhanpeisova, 2004).

\section{Methodological Framework}

Paroemias about a family reflect the arrangement of the "inner" world of a person, relationships in a family and starting a family, domestic happiness. Numerous Russian and Yemeni proverbs about a family prove the fact that family is important for a person. A group of proverbs about a family reveal very close semantic connections with proverbs of other groups. This explains the predominance of the given group of proverb and the priority of its consideration. The following features are revealed during the analysis:

1) Love for a family and Homeland is reflected in the proverbs of both nations. We fully agree with L.K. Bairamova, who writes that "concept Homeland has deep historical and cultural roots and is reflected in lexical and phraseological systems of different languages" (Bairamova, 2002).

بيتي بيتي ياساتر عورني $\quad$ Beiti beiti ja satr orati - My house is my castle (El sakaf, 2004).

'iz il-khaīl šbūlhā wa law qalla il-ĥashīsh A horse is proud of its stables, no matter how poorly he is fed.

iz el baduwi beito - A Bedouin's pride is his house.

Man shaf khemat al sultan la ehraq arishu He, who has seen other people's palaces, will not ruin his hut.

A similar notion is reflected in Russian proverbs:

Родная хижина милее каменных палат. Rodnaya khizhina mileye kamennyh palat.- One's own hut is better than stone palaces.

Свой уголок всего краше. Svoy ugolok vsego krashe - One's own place is best of all.

Везде (в гостях) хорошо, а дома лучше.Vezde (v gostyah) khorosho, a doma luchshe - It feels good everywhere (at other people's places), but home is best.

2) In Russian and Yemeni paroemias the category of family can be presented by means of associate words. Thus, in Arab proverbs the given category is represented by means of the following lexemes - stables, well, tree, hut, man of a house, camelcade, nails, blood. In Russian proverbs it is done by means of the lexemes - mother, bog, herd, a site of fire, nest, bread, ship, stove

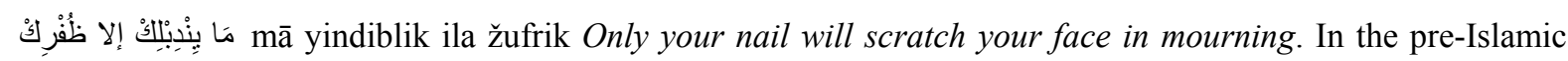
period Arabs used to have an ancient custom: women mourning for the dead scratched their faces with nails until blood came out to soften the loss. It should be noted that this custom does not exist anymore. A nail in this 
proverb is the representation of a close relative, as it is a part of the body. The meaning of the proverb is - Only close relatives will sincerely suffer grief at the death of a person.

umr id-dam maesboh ma - Blood will never turn into water. The meaning is - Members of the family will never stay indifferent to the problems of a relative and will always help.

ما يحك للك ظهرك زي ظفرك ma uhok lak dahrak zei zifrak - No one will scratch you better, than your own nail.

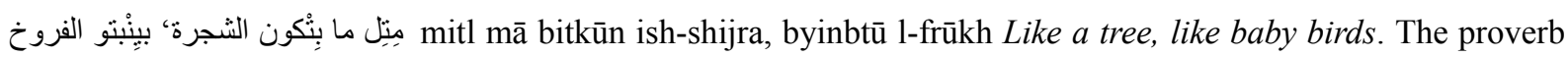
draws a comparison between a family and a tree. If a tree is strong and has rich foliage and many fruits, the baby birds living on the tree will never be hungry and grow up big and strong. The same is true regarding the family: if it is strong and unalterable, the children will become true children of their parents.

By means of different associations the idea that home is a guarantor of peace and tranquility, success, wellbeing and safety is represented in Russian proverbs as well:

В своей хатке, что у родной матки под пазушкой. V svoyei hatke shto u rodnoi matki za pazushkoi.- Being at home is like being under your mother's wing. It should be noted that this proverb presents comparison, which cannot be found in Yemeni proverbs.

В своем болоте и лягушка поет. V svoyom bolote I lyagushka poyot. - Even a frog sings in its own bog. Explanation of the secrets of success, when all the abilities of a person are revealed at home where one feels safe, peaceful, so that one can cope with everything.

В согласном стаде волк не страмен. V soglasnom stade volk ne strashen. - A wolf is not a threat to a united herd.

И воробей свое гнездо любит. I vorobey svoyo gnezdo lyubit - A sparrow loves its nest.

3) An important and responsible role of a man in the house, in the family, his role in children's upbringing is highlighted in Russian and Yemeni paroemias.

iza saheb el beit tabal faahlo rakkasin - If the man of the house is a drummer, all the family members are dancers.

ibn il far hafar- A son of a mouse digs well.

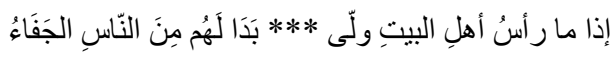

The necessity of having a man in the house can be traced in Russian proverbs as well:

Без хозяина дом сирота. Bez khozyaina dom sirota - A house is an orphan without a man.

Не по постройке дом, а по хозяину ценится. Ne po postroike dom, a po khozyainu tcenitsa. - It's not the construction, but the man of the house that makes it recognized.

Хозяин в доме всему голова. Khоzyain $v$ dome vsemu golova - A man is the head of the house.

It should be noted that the image of the woman of the house is reflected in Russian paroemias, which cannot be found in Yemeni proverbs due to specific features of their worldview: it has always been considered that a Man is the head of the family.

Обед не в обед, коли хозяйки нет. Obed ne v obed koli khozyaiki net. - You cannot enjoy dinner, if there is no woman of the house.

Чем умнее жена, тем сильнее семья. Cheт итпеуе zhena, tem sil'neye sem'ya. - The smarter is the wife, the stronger is the family.

4) Yemeni paroemias much more often than Russian proverbs say that a man can cause anger and displeasure with his family for his ill acts. It can be explained by a harder nature of Arabs.

مبيته بينفعنا كبر فجعنا rabbetoh baimfana kabar fajana - he was brought up as a helper, he grew up and scared us. A tight man, a man of coarse grain is usually called "a son of affliction" in Arabic. Such person tends to break rules of morality and behavior, which results in insulting not only the initiator, but his family as well.

يقاقلبي ما ينفعك حنيت السم والعله من اهل البيت ja kalbi mainfak hannet el sum wel el la min ahlil beit - One's heart aches when the cause of trouble and poison is a relative. The proverb reflects the idea that worst of all is when your close people cause you harm.

Similar thoughts can be seen in Russian proverbs as well:

В семье не без урода. V sem'ye ne bez uroda - In every family there is a monster. This is how people 
disapprovingly call a person, different from other members of the family in his bad habits, character, acts and behavior. The Arab equivalent of the proverb is: في كل قبيلة هييلة fì kul qabīla habīla Every tribe has a silly one.

В семье не без урода, а на урода все не в угоду. V sem'ye ne bez uroda, a na uroda vsyo ne v ugodu - In every family there is a monster, and nothing can please a monster.

5) Both Russian and Yemeni proverbs reflect negative attitude to a person who is kind and lovely with other people, but displays nasty character and behavior at home.

harigi el beit lil margalah we bel beit hati ja mara - A man out of home, a layabout at home.

Māa abkhalak bibaytak, wa akramak bibyūt in-nās! How greedy you are at home, and generous at other people's homes! The meaning is as follows: some people disguise the shortcomings in public and behave differently with family members.

The same admonition to respect the rules of etiquette at home can be found in Russian proverbs as well:

Не будь в людях приметлив, будь дома приветлив. Ne bud'v lyudyah primetliv, bud' doma privetliv. - Don't be noticeable in public, be affable at home.

В людях - Ангел, дома - черт (бес). Vlyudyah Angel, doma chyort (bes). - An angel in public, a devil (demon) at home.

В гостях Илья, а дома свинья. V gostyah Il'ya, doma svin'ya - Il'ya(name) in public, a pig at home.

6) Both Russian and Yemeni paroemias approve of some privacy in the family. The proverbs also encourage people not to talk about the things that happen at home in public:

عنتر مام الناس وفي بيته صبي anter amam el nas wi fi el beit sabi - A brave man in public, a child at home. A man can stop being serious at his home and even start joking.

Russian proverbs also encourage people not to discuss family matters in public:

Сор из избы не выносят. Sor iz izby nе vynosyat - Don't wash dirty linen out of home.

Выметай, но сору из хаты не выноси.Vyтеtai, no soru iz khaty ne vynosi. - Don't wash dirty linen out of home.

У каждой избушки свои побрякушки. U kazhdoi izbushki svoii pobryakushki. - Every house has its own peculiarities.

The latter postulates the fact that there is something specific, not to be made public in every family, which makes the given proverbs more judgmental.

7) Yemeni paroemias, unlike Russian ones, have a characteristic metaphor, when the lexeme "family" itself is a metaphor and represents something else.

kullu yati ma huwa lahu ahlun Everyone meets his family. This proverb is interpreted as follows: every man meets his actions and statements. It is used to draw a parallel between the actions and the nature of the subject. Here, the word "family" refers to the actions and statements of the person.

8) In Yemeni paroemias, unlike Russian ones, often qualitative lexeme, describing people, are used in combination with the word "family". Firstly, there can be seen a metaphorical image of the word "family". As one cannot get rid of a family kinship, people used to say "family greed" when they highlight the impossibility of eradicating certain quality of this family. Thus, the meaning of "family greed" is much more expressive than the combination of "greedy people." Along with the expression "family of greed", we identified "family of evil", "family of weakness", "family of silence", "family of ignorance", indicating the widespread range of expressions of this type.

ahl el akul ifhamu men kamza wilgahel ifhamu min rafsa - reasonable family understands at a glance, and dull - with a kick. A smart family is implied under a family of reason.

9) Yemeni paroemias held the idea that the family is not able to betray its members and the importance of family members is more substantial than the value of friends. It is noteworthy that in the analyzed Russian paroemias no similar ideas were revealed. Perhaps this underscores the fact that the family betrayals were considered priory unacceptable, and therefore were not reflected in paroemias.

ma dahal bukum huzki el hanash kalu ibnina fih - they were asked what had got them into the viper's nest. They said that their son was there. I.e. parents will never leave their baby and are 
willing to sacrifice themselves.

عُمرْ الدَّم م ايصبح مَاءْ the blood relatives would never react with indifference to the problems of a man and are always ready to help in case of trouble.

10) In some Yemeni paroemias, in contrast to Russian ones, the idea that a man can leave his family for a long time taking a trip is reflected. In our opinion, this is due to the fact that the Arabs have long led nomadic life, went on hikes for a long time, leaving their families.

إذا رجعت من السفر قدم لأهلك ولو حجر idh ā raja 't min is - safar qaddim liahlika wa law $\hat{\mathrm{h}}$ ajar If you have returned from your trip, then fetch at least a stone for your family.

11) In some Yemeni paroemias the idea of defending your own home from the attack is brightly outlined. In the same group of Russian paroemias it is not observed. We believe that this fact indicates more rigid morals prevailing in the East, in the Arab world.

iza taharabat al ku rud haf ala beitak - if monkeys have a fight, defend your home. I.E. do not be distracted by other people's problems, look after your own home.

اذا جاء المغرب اققل باب بيت وزرب iza ja el magrib kaffil bab beitak wezarrib - if it gets dark, close the gates and protect your home.

ifla ĥ ar đak, wi stir 'ar đak Cultivate your land and defend your honor. The thing is that the Arabs personal land is considered as the part of their own honor and dignity. It should be noticed that the Arabic word ard "earth" and 'ard «honor" are almost similar phonetically and the difference is only in the first letter.

illi beito min zigag ma ergimsh biut al nas Those who have a glass house, shouldn't throw stones (to other homes).

12) In this group of Yemeni paroemias containing a parable in its base the humor related with the family is seen. In these Russian paroemias we have not identified such an anecdotal humor.

ذكَّرَني فُوكِ حمارَي أهلي dhakkrani fuki himaray ahli. Your mouth reminded me of two donkeys of my family.

There is a parable. Once a Yemeni family lost two donkeys. The man went to look for donkeys and met a tall woman in a burqa with beautiful eyes. The man really liked the woman, and, despite the fact that her face was covered, the man forgot about the donkeys and began to talk to her. In the course of conversation, the veil accidentally fell off the face of the woman for a moment, and displayed a man her mouth with protruding front teeth. And in this moment the man remembered the donkeys and uttered the phrase, which later became famous: "Your mouth reminded me of two donkeys of my family."

13) Considered Russian paroemias oppose discord in the family. According to E.V. Ivanova, "the idea of the existence of disorder in every family, even the most prosperous one in plain view, is very widespread and deeply rooted" (Ivanova, 2004). It should be noted that the Yemeni paroemias that describe disorders in the family, are hardly detected. Perhaps this is due to the fact that in Yemen men reserve dominant position in the family, and the man's decision is indisputable.

Consequently, quarrels in the family principally are impossible.

Большое горе, когда семья в раздоре. Bolshoye gore, kogda semya v razdore. - It is a great sorrow, when the family is in discord. 
В недружной семье добра не бывает. V nedruzhnoy semye dobra ne bivayet.- In an unharmonious family good things do not happen.

Не будет добра, коли в семье вражда. Ne budet dobra, koli v semye vrazhda.- Good things will not happen, if there is feud in the family.

It is noteworthy that among the reviewed Russian paroemias we identified paroemias, which state that the quarrel goes for the benefit of the household.

Семейная ссора - что весенний дождь. Seтеynaya ssora - chto vesenniy dozhd' - Family quarrel is like a spring rain.

Ссора в своей семье до первого взгляда .Ssora v svoyey semye do pervogo vzglyada.- The quarrel in the family is until the first glance.

14) Some Russian paroemias encourage the households to be together and not to be lonely. Among Yemeni paroemias this appeal is not revealed. In our opinion, this is due to the fact that people in Yemen for centuries lived in large families in the neighborhood with each other, and a man could not stay alone, because he always could rely on the help of the relatives.

Вся семья вместе, так и душа на месте. Vsya semya vmestye, tak dusha na mestye.- The whole family together and soul is on the spot. (Family that prays together stays together) It is said with satisfaction when all households are returning home after a hard work, various tests, etc.

Hа миру и смерть красна. Na miru I smert' krasna. - In the world, and the death is red. (Company in distress makes trouble less.) Death and disaster is not so terrible if a man is not alone. It should be noted that the expression "in the world" refers to human society. The word "world" in pre-revolutionary Russia meant rustic peasant community.

Семья в куче - не страшна и туча. Seтуa v kuche - ne strashna I tucha. - If a family is in heap they are not afraid of any cloud.

Семья - печка: как холодно - все к ней собираются. Semya - pechka: kak holodno - vsye k ney sobirautsya. Family is an oven, when it is cold - all gather around it.

\section{Results}

According to quantitative indicators, Russian paroemias which contain the component of family relations considerably exceed the number of Yemeni paroemias of the similar content. In Russian and Yemeni paroemias the importance and significance of such notions as family and Motherland is stated. Moreover the idea of the supreme nature of family, primary role of man in a house, family, bringing up children are typical for both nations. In Russian paroemias a woman is characterized as a good housekeeper which is not the same for Yemeni paroemias that reflect the oriental mentality distinguished by depersonalizing of a woman.

In Yemeni paroemias it is more frequently stated that a person can cause anger and disgrace of his family for some offences, which confirms the severity of Arab customs. Both Yemeni paroemias and Russian ones affirm disapproval of cruelty towards the family and relatives. Yemeni and Russian paroemias approve of living in retirement at home among family. Some paroemias appeal not to tell about events occurring in the family. In contrast to Russian paroemias, Yemeni ones are characterized by using lexeme "Family" in periphrastic phrases. Thus the phrase "the family of greed" means a group of greedy people. We have distinguished the following phrases: "the family of greed", "the family of evil", "family of weakness", "family of silence", "the family of ignorance".

In some Yemeni paroemias the idea of impossibility of betraying a member of the family is represented. It is noteworthy that in the analyzed Russian paroemias this idea is not revealed. Perhaps it means that the betrayal of the family was considered a priori invalid and was not reflected in paroemias.

In certain Yemeni paroemias in contrast to Russian ones the thought of long-term leaving a family is traced. In our opinion it is explained by the nomadic lifestyle specific to the Yemenites and their long trips far from their family. Some Yemeni paroemias forcibly express the idea of preserving one's own home from the attack. In Russian paroemias of this group this idea is not revealed, which in our point of view, underlines the cruelty of the Arab world customs.

A large number of Russian paroemias opposes discords in a family. As for the Yemeni paroemias that disapprove family discords there are hardly any of them which can be found. Perhaps it can be explained due to the fact that in Yemen dominant position in the family is assigned to a man. The opinion of man is indisputable and eliminates a possibility of any contentions. Some Russian paroemias are devoted to the description of a lonely 
human existence. The purpose of these paroemias is to appeal to a change in marital status. Among Yemeni paroemias such a theme was not identified which can be explained as follows: for centuries Yemenis have been living in large families in the neighborhood with each other. Therefore one could not stay alone, because he always could rely upon the help of relatives.

\section{Discussions}

The problem of studying small genres of folklore in the aspect of ratio of the language and culture is not new in Russian studies and in the comparative-typological linguistics as well (L.G. Permyakov (1988), N.F.Alefirenko (2010), N.N. Fattakhova (2004), G.A.Bagautdinova (2007), L.K.Bayramova (2002), T.G.Bochina (2003), N.M. Zhanpeisova (2004), E.V.Ivanova (2002, 2004), V.A. Maslova (2005), etc.), however, there are not enough studies that reveal the ethno-cultural specificity of paroemias appealing to internal form that reflects the outdated realities, symbols, customs and traditions.

In addition, despite the existence of a series of monographic works (E.V. Kukhareva (2008), V.D. Ushakov (1996)), steady structures in the Arabic language were not linguistically described. Taking into account modern aspects of the study, they are considered either in the works devoted to literary criticism, sociology, social psychologist (V.E. Shagall $(2001,2008)$, G.S. Sharbatov (1961), etc) or fragmentarily in the linguistical works, often in lexicographical aspect (Raghib al-Asfahani (1998), Imil Jakub (2004), Ahmad Al-Maydani (2007) H.K. Baranov (1994), V.F. Polikanov (2005), etc.). This article describes fixed structures in the Yemeni dialect of Arabic which have not yet been studied in terms of their language and culture.

\section{Conclusion}

Comparison of paroemias in languages with different structures gives the right to conclude that there are common allegorical meanings expressed while there are doubtlessly more or less publically-national differences of the embodiment of ideas through imagery and emotional-subject concreteness. Comparative study of paroemias of structurally different languages is extremely important, because it is comparative paroemiology that is a valuable source of information about the culture, stereotypes of people's consciousness, which reflect the vision of people about morality, customs and traditions, becoming the property of linguistic consciousness.

Conducted study on the comparative analysis of Russian and Yemeni paroemias, reflecting the specificity of family relationships in the conceptual-semantic and ethno-cultural aspects allowed presenting a number of research results:

- Lingvo-cultural studies were found to enable the implementation of the cognitive approach to the comparative study of paroemias in order to identify their ethnic and cultural identity. Comparative investigation of paroemias with component-name of family relationships made it possible to establish a universal and specific features in their system and speech representation and suggest new version ethno-mental and normative-evaluative conditioning similarities and differences;

- It was revealed that many of the components that are considered national-specific only for the Russian-speaking consciousness match the Yemeni dialect of Arabic, where they also act as keywords in the equivalent paroemias;

- It was proved that the discrepancy in the semantics of some paroemias in the considered languages can be found in the syntagmatic and paradigmatic differences that occur between the content and the structure of paroemias and denoted realities;

- It was found that paroemias oriented at conceptual-semantic field of "man" in terms of family relationships, absorb a whole range of characteristics on various parameters, explicating the mosaic of national cultures on the semantic and structural levels, and being a valuable source of knowledge on originality of different linguistic pictures of world's nations;

- The essential characteristics of paroemias and sayings, as manifested in the semantic aspect and the functional diversity of the context of their use were disclosed;

- Valuable references in the study of national paroemiological pictures of the world were compared. The cases of discrepancies of paroemias in different structured languages on associative imagery and value-evaluation levels were studied.

The spiritual life of the nation, ethnic group mentality are reflected in the component names, which are used by every individual in their cognitive activity. 


\section{Recommendations}

The information in the article provides the usage of theoretical material and linguistic base in teaching vocabulary of modern Russian and Arabic languages, Arabic language dialects courses, as well as linguistics, intercultural communication, special courses involving issues of language and culture on the field of "Linguistics", "Philology". Applied value of the work is defined as the ability of practical material usage in compiling textbooks, study guides and dictionaries in Arabic and Russian languages.

\section{Acknowledgments}

This work was funded by the subsidy allocated to Kazan Federal University for the state assignment in the sphere of scientific activities

\section{References}

Al - asfakhani, A. (1998) Obyasneniye neobychnykh slov Korana. Beyrut: 569.

Al' maydani, A. M. (2007) Sbornik pogovorok i poslovits. Sayda: 418.

Alefirenko, N. F. (2010). Lingvokul'turologiya: tsennostno-smyslovoye prostranstvo yazyka: Ucheb. PosobiyeMoskva: 288.

Bagautdinova, G. A. (2007). Chelovek vo frazeologii: antropotsentricheskiy i aksiologicheskiye aspekty: avtoref dis. d-ra filol. nauk. Kazan: 45.

Baranov K. K. (1994). Arabsko-russkiy slovar'. Tashkent: 912.

Bayramova, L. K. (2002). Ponyatiye Rodiny v russkoy i tatarskoy leksike i paremii. Tezisy dokladov III Mezhdunarodnoy nauchnoy konferentsii. Naberezhnyye Chelny: 24-25.

Belova, A. G. (1999). Ocherki po istorii arabskogo yazyka. Moskva: 168.

Bochina, T. G. (2003). Kontrast kak lingvokognitivnyy printsip russkoy poslovitsy: dis. d-ra. filol. nauk. Kazan: 449.

Dal', V. (1955). Tolkovyy slovar' zhivogo velikorusskogo yazyka. T. 4. Moskva: 683.

Fattahova, N. N. (2004). Narodnye primety $v$ russkom i tatarskom jazykah: semantiko-sintaksicheskie otnoshenija. Kazan: 192.

Imil' yakub. (2004). Narodnyye pogovorki Livana. Tripoli: 200.

Ivanova, E. V. (2002). Angliyskiye i russkiye poslovitsy o sem'ye. Vestnik Sankt-Peterburgskogo un-ta: 138.

Ivanova, E. V. (2004). Poslovichnaya kontseptualizatsiya mira (na materiale angliyskikh i russkikh poslovits): dis. d-ra. filol. nauk. Sankt-Peterburg: 414.

Jel' sakaf Intiba as said abu bakr. (2004). Narodnye adenskie poslovicy. Sana: 191.

Kukhareva, E. V. (2008). Arabskiye poslovitsy i pogovorki. Slovar' s leksiko-frazeologicheskimi kommentariyami. Moskva: 303.

Maslova, V. A. (2005). Kognitivnaya lingvistika: ucheb.posobiye. Moskva: 256.

Ozhegov, S. I. (2007). Tolkovyy slovar' russkogo yazyka. Moskva: 944.

Permjakov, G. L. (1988). Osnovy strukturnoj paremiologii. Moskva: 235.

Shagal', V. E. (2001). Arabskij mir: Puti poznanija: Mezhkul'turnaja kommunikacija i arabskij jazyk. Moskva: 288.

Shagal', V. E. (2008). Kul'tura povsednevnosti v arabo-musul'manskom mire: Uchebnoe posobie dlja studentov. uglublenno izuchajushhih teologiju i arabskij jazyk. Moskva: 395.

Sharbatov, G. Sh. (1961). Sovremennyj arabskij jazyk. Moskva: 112.

Tolkovyj slovar' arabskogo jazyka «al' magem al' vasid». (2012). Kair: 1200.

Tolkovyj slovar' arabskogo jazyka «al' mundzhid al' abzhadi». (2014). Bejrut: 1174.

Ushakov, V. D. (1996). Frazeologija Korana: Opyt sopostavlenija frazeorechenij Korana i arabskogo klassicheskogo jazyka. Moskva: 203.

Zhanpeisova, N. M. (2004). Reprezentatsiya natsional'nykh kontseptosfer v kartine mira kazakhsko-russkikh bilingvov: avtoref. dis. d-ra filol. nauk. Ufa: 42. 


\section{Copyrights}

Copyright for this article is retained by the author(s), with first publication rights granted to the journal.

This is an open-access article distributed under the terms and conditions of the Creative Commons Attribution license (http://creativecommons.org/licenses/by/3.0/). 